\title{
Seasonal variation in the regional structure of warming across China in the past half century
}

\author{
Yuanqing $\mathrm{He}^{1,2,3}$, Aigang $\mathrm{Lu}^{2, *}$, Zhonglin Zhang ${ }^{2}$, Hongxi Pang ${ }^{2}$, Jingdong Zhao ${ }^{2}$ \\ ${ }^{1}$ The School of Geographical Sciences, Nanjing Normal University, Jiangsu, Ninghai Road 122, Nanjing 210097, China \\ ${ }^{2}$ Cold and Arid Regions Environmental and Engineering Institute, Chinese Academy of Sciences, \\ Donggang West Road 260, Gansu, Lanzhou 730000, China \\ ${ }^{3}$ The Institute of Tibet Research, Chinese Academy of Sciences, Beijing 100029, China
}

\begin{abstract}
A dataset of 160 National Meteorological Observatory stations with long-term monthly temperature data for China was analyzed to assess the seasonal variation of the spatial temperature structure across China in the past half century. Different warming trends were found for the different seasons: the extent of warming is stronger and more widespread in winter than in summer. Warming is more pronounced at higher latitude, particularly in winter. The possible mechanisms of seasonal variation in climate warming include effects of greenhouse gases, increased cloud cover due to increases in sulfate aerosols, and local processes such as changes in land use and urban heat island effects.
\end{abstract}

KEY WORDS: Global warming $\cdot$ Regional structure $\cdot$ Seasonal variation $\cdot$ Mechanism Resale or republication not permitted without written consent of the publisher

\section{INTRODUCTION}

China has a typical continental monsoon climate that varies greatly between seasons, especially between winter and summer. Thus, it is relevant to study the seasonal difference of climate in China. In an earlier study (Lu et al. 2004) analyzed the regional structure of global warming across China using the definition of warming-up points (mutation points) over various regions of China. In this study, we provide additional results on the regional warming structure across China during the second half of the 20th century, based on a long-term (52 yr) monthly temperature dataset from 160 stations maintained by the National Meteorological Observatory (NMO) in China. The warming-up points were calculated using the procedure described by Lu et al. (2004).

\section{DATA AND METHODOLOGY}

The dataset from 160 NMO stations with longterm monthly temperature data was provided by the
National Climatic Center (NCCC) of the China Meteorological Administration (CMA) and contains values from January 1951 to December 2002. The density of stations is lower in the sparsely populated high mountainous and desert areas of western and NW China, and especially on the Tibetan Plateau (Fig. 1). The Mann-Kendall trend test (Mann 1945, Kendall 1955), a widely used non-parametric test for detecting trends in time series, described in Lu et al. (2004), was used in this follow-up study to evaluate whether there was any sharp change in seasonal temperature at each station during the past 52 years. The significance levels in this study were $\alpha=$ 0.05 . We denominate a year with a sharp change in temperature a 'mutation point', or simply mutation. The analyzed mutation points for each station were compared with one another, to determine the relative response to global warming at different locations and in various seasons in China. In addition, correlation analysis was applied to determine the seasonal pattern of temperature changes across China. 


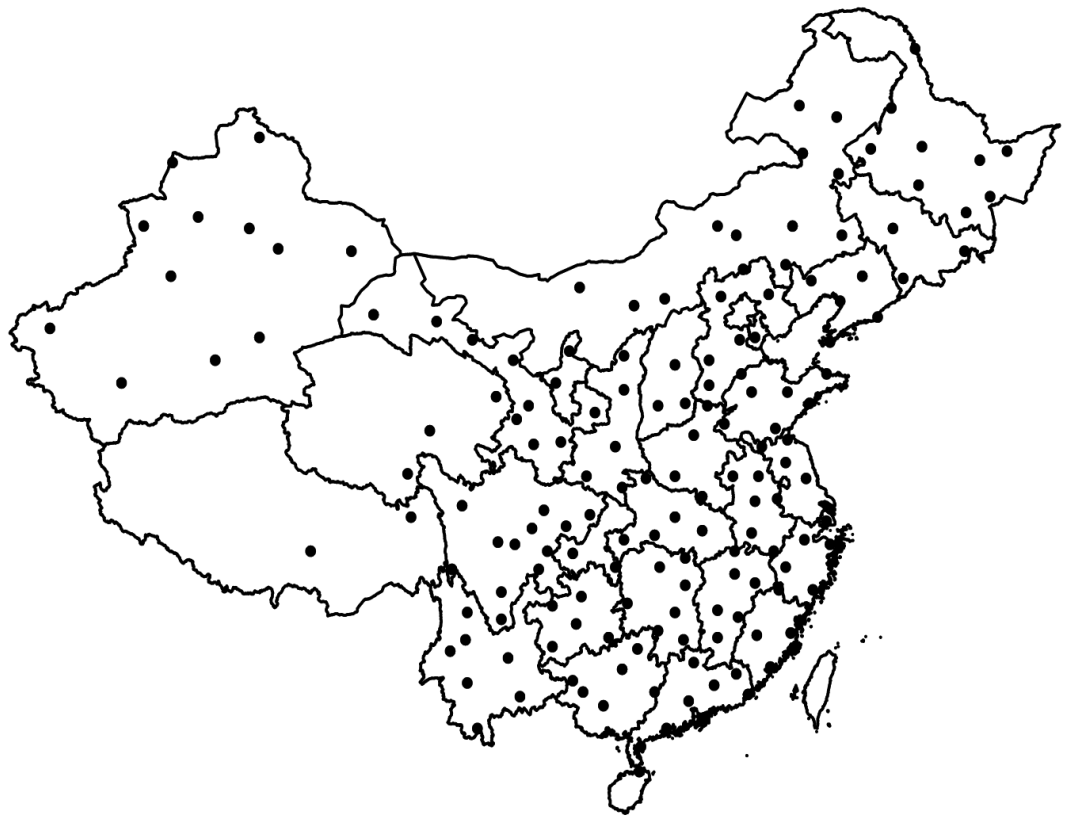

Fig. 1. Location of the 160 meteorological stations analyzed, showing administrative regions in China

warming mutation, except in SW China. The stations with a significant cooling mutation are located in Szechwan and Yunnan. Unlike the widespread pattern in summer, the winter pattern is more regionalized.

There exists a temperature decline in SW China all year round. The same result, a temperature decline in SW China from the 1950s to the 1980s, was obtained by Ding \& Dai (1994). They suggested that this resulted from the influence of the Tibetan Plateau. By using a latitudinal average energy balance model, Birchfield \& Wertman (1983) found that average land surface temperature in the Northern Hemisphere would rise linearly with an increase in solar radiation, if there were no influence by landforms. From an ice core study, Thompson et al. (1997) found that historically the climate in Tibet has cooled rapidly, and warmed slowly. Thus, the lag in the response of Tibet to global warming could exert dynamical

\section{RESULTS AND DISCUSSION}

\subsection{Seasonal structure of regional temperature variation}

The Mann-Kendall trend test result for summer temperature (Fig. 2), shows 4 groups of stations with different variation trends and significance: 50 stations with a significant warming mutation are distributed in clusters in NE, western and southern China; 40 stations with a significant cooling mutation are clustered across eastcentral and NW China; 64 stations have a not significant warming trend; 6 stations have a not significant cooling trend. The distributions of stations with different temperature variation trends indicates that warming and cooling in summer are regional, not general, phenomena, and largely due to local factors.

Fig. 3 shows the Mann-Kendall test result for the winter temperature. There are more stations with a significant warming mutation and fewer stations with a significant temperature decline mutation than in summer. Overall, there are 3 groups: 120 stations with significant warming mutations, 32 with a not significant warming trend, and 8 with significant cooling mutations. Therefore, there is a significant and thermal influences on the surrounding climate, e.g. by increasing temperature differences and atmospheric circulation between the Tibetan Plateau and the surrounding regions. The strengthened circulation results in a temperature decline in the areas around Tibet, so that these areas also lag in warming, compared to other areas. Especially in summer, relatively warm air over the plateau rises and then descends in

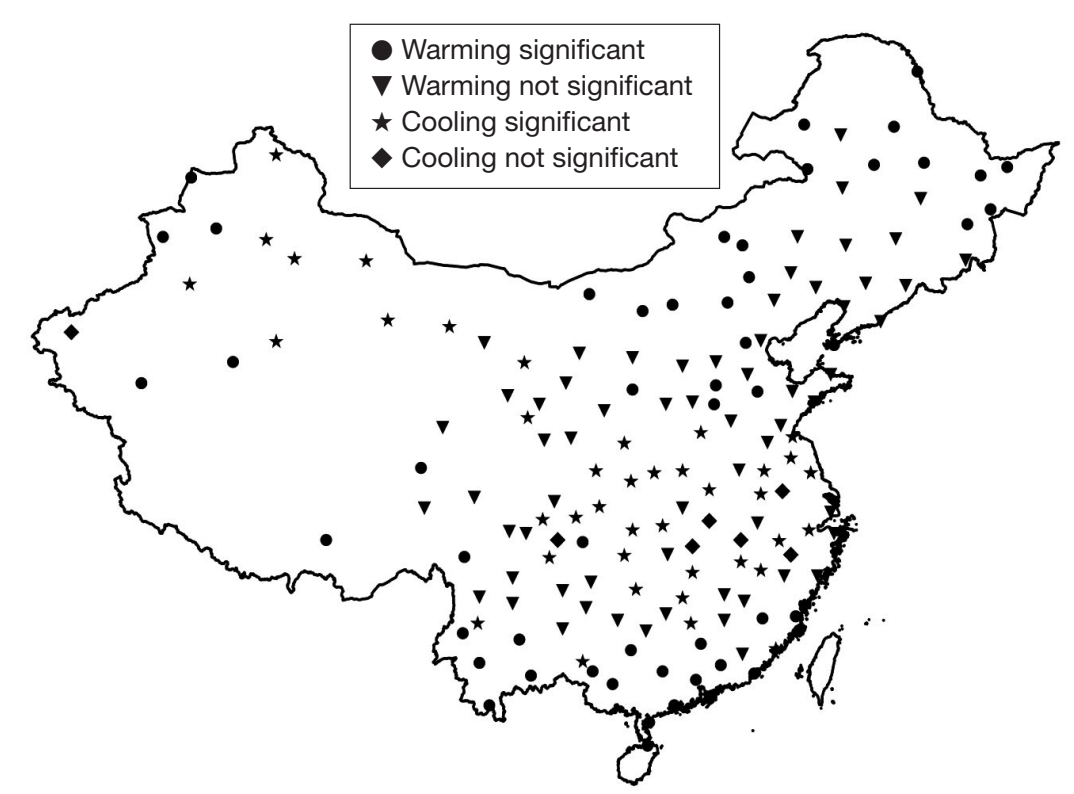

Fig. 2. Trends of change in summer temperature in China for 1951-2002 


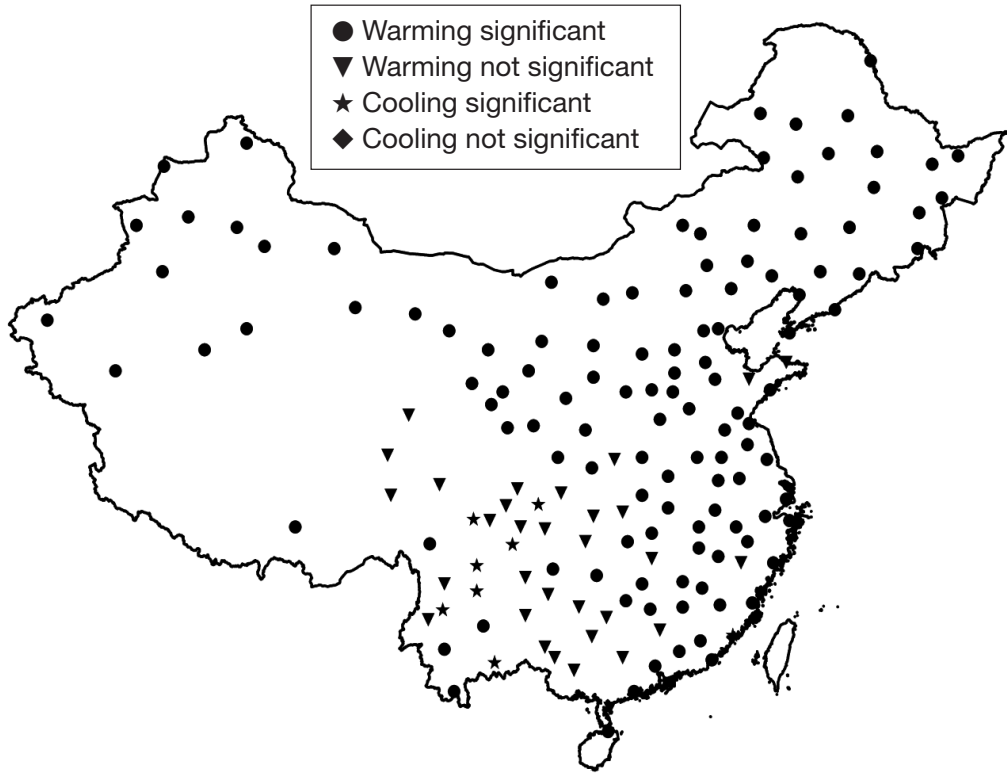

Fig. 3. Trends of change in winter temperature in China for 1951-2002

characterized by a decrease in total and direct radiation, and a small increase in diffuse radiation; they found a negative linear relationship between a clearness index and diffuse radiation, and they concluded that the increase in air pollution and decrease in relative sunshine cause a decrease in total and direct radiation. Qian \& Giorgi (2000) observed a statistically significant cooling trend over the Sichuan Basin of SW China associated with increasing atmospheric aerosol optical density. Therefore, regional temperature decreases in China are also due to the increasing atmospheric aerosol concentrations.

\subsection{Seasonal structure of regional temperature variation}

The extent of temperature increase was analyzed spatially by Lu et al. (2004). To show the seasonal temperature increase

the neighboring areas, and this results in a vast region of temperature decline. In winter the high pressure over the Tibetan Plateau attracts the Mongolia High Pressure system, and the resulting much stronger high pressure leads to airflow southward down the SE margin of the plateau and causes a decline in temperature in the corresponding area. Moreover, in summer the westerly winds are divided by the plateau and their northern branch follows the northern margin of Tibet; this poleward airflow causes the temperature to increase to the north of Tibet, counteracting the previous cooling effect. However, to the east of Tibet the equatorward airflow leads to a temperature decrease, compounding the plateau-induced temperature decline; the combined effect overrides the global warming trend.

Sulfate aerosols also influence the temperature records from the 160 stations. Surface cooling caused by increased concentrations of short-lived sulfate aerosols has masked underlying climatic trends over several industrial areas (Mitchell \& Johns 1997). Similarly, heating of urban meteorological stations has long been suspected to mask the warming due to greenhouse gas emissions. By analyzing global direct and diffuse solar radiation data on horizontal surfaces at stations in Shanghai, Nanjing and Hangzhou for the period from 1961 to 2000, Zhang et al. (2004) found that eastern China is

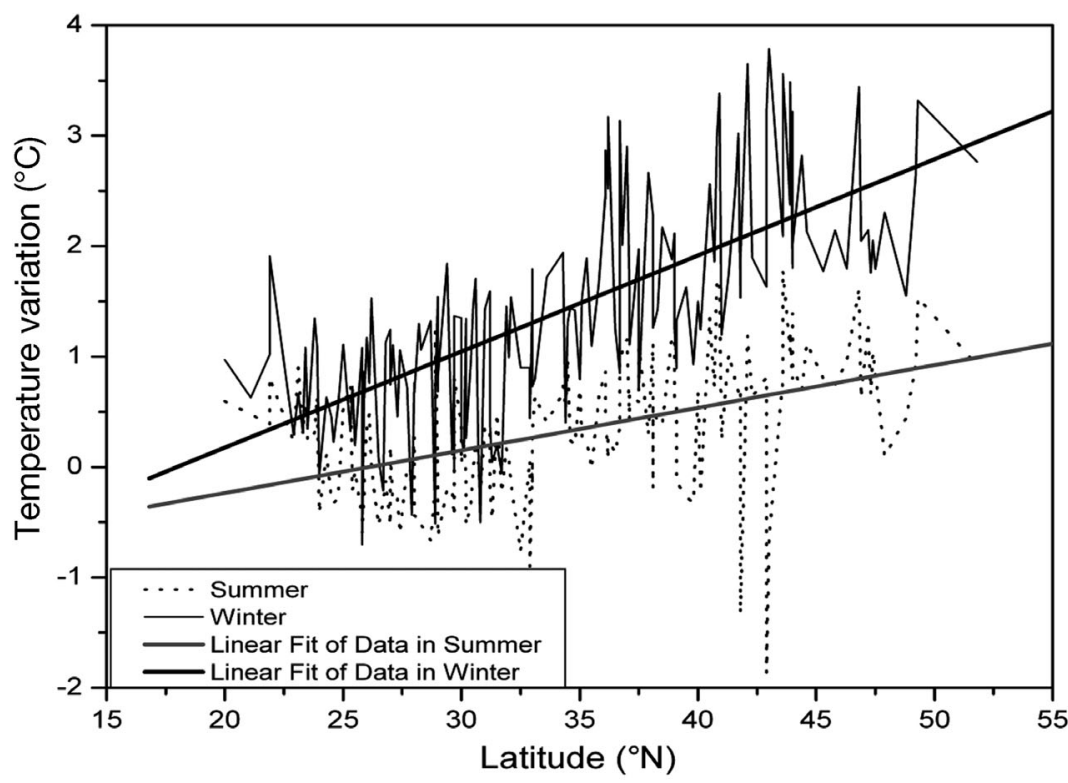

Fig. 4. Latitudinal distribution of the extent of warming in China extent, we calculated winter and summer temperature differences at each station between the periods 1951-1960 and 1993-2002. The latitudinal distribution of the seasonal temperature variation difference (Fig. 4) shows that the extent of warming increases with increasing latitude, and that this is more pronounced in winter. In addition, warming in winter is much greater than in summer at each station, and the difference increases with latitude. This is similar to results for the west coast of the Antarctic Peninsula obtained by Vaughan et al. (2003), who concluded 
that winter temperatures have greater variability than summer temperatures. Chapman \& Walsh (1993) and Serreze et al. (2000) also found that the strongest warming has occurred during the winter and spring. Based on China's observational data from 1951-1990, Zhai \& Ren (1997) found that minimum temperatures were generally increasing throughout China, with dominant warming trends at the higher latitudes. Also, Liu \& Leopold (2003) found that between 2 and 3.1 million yr BP the temperature in North China oscillated cyclically, with a declining trend in mean annual temperature, largely as a result of colder winter temperatures; they noted that temperature gradient from the North Pole to mid-latitudes was fairly flat when the pole was warm, but 1.5 to 2 times steeper when the pole was cold. Therefore, temperature variation increases at higher latitudes. Research on the Mid-Holocene optimum (Du et al. 1989, An et al. 1990, Kong et al. 1991, Tang et al. 1991, Shi \& Kong 1993, Zhang 1993, Yao et al. 1998) indicates that $6000 \mathrm{yr}$ BP winter temperature in eastern China was $2.5^{\circ} \mathrm{C}$ higher at present, and that in western China it was 3 to $4^{\circ} \mathrm{C}$ higher. Winter warming also occurred in North America in the MidHolocene optimum (Wright et al. 1993).

Spatial differences in the extent of temperature variation probably result from the different continentalities of the mid- to high latitude areas. Continentality generally increases with latitude in China, and the higher latitude region is more sensitive to a global change than the lower latitude region. Furthermore, the vegetation growing period is shorter at higher latitudes. The increase in vegetation in the summer can change the thermal capacity of the land surface in northern China, resulting in a greenhouse-like effect (Chen et

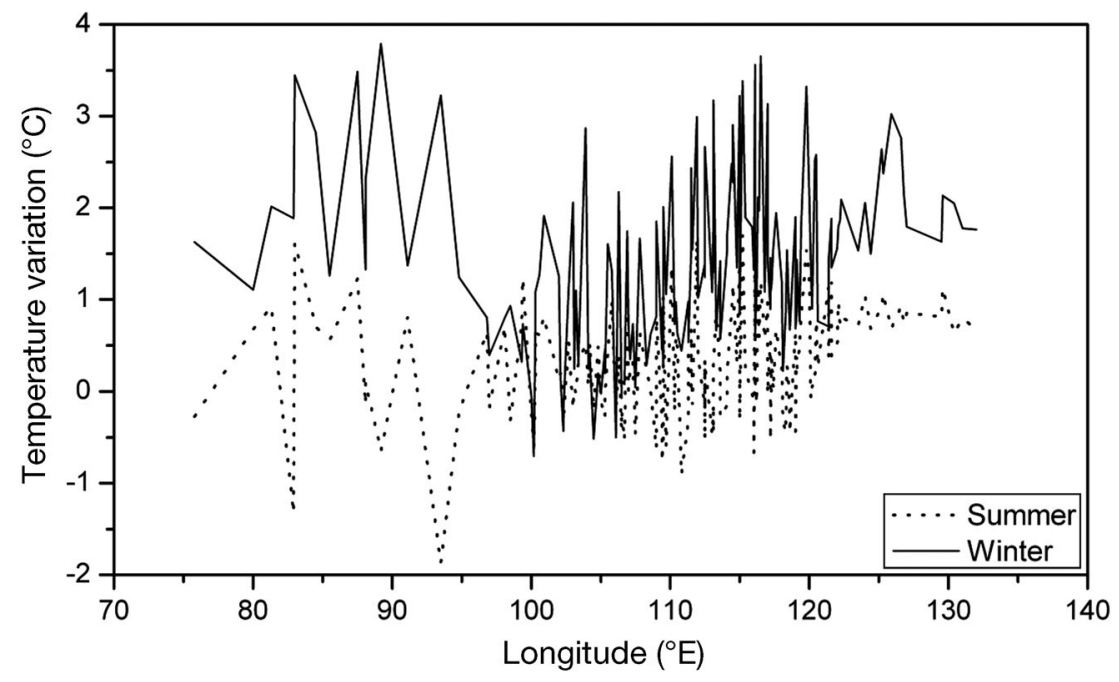

Fig. 5. Longitudinal distribution of the extent of warming in China al. 2002). This effect disappears during defoliation in winter.

The longitudinal distribution of seasonal warming (Fig. 5) equally shows that warming is greater in winter than in summer, especially between $97^{\circ}$ and $120^{\circ} \mathrm{E}$; this may partly result from the influence of the Tibetan Plateau in the west and the ocean in the east, and partly from the latitude effect, because the stations between $97^{\circ}$ and $120^{\circ} \mathrm{E}$ are more numerous at higher latitude. Thus the longitude differences in seasonal warming are a combined result of land form, ocean and latitude influences. A marked difference appears around $94^{\circ} \mathrm{E}$, which is similar to the grid data analyzed by Lu et al. (2004).

\subsection{Anthropogenic effects and global temperature change}

\subsubsection{Greenhouse gas induced warming}

Laat \& Maurellis (2003) found that temperature changes measured over the last 2 decades are locally or regionally related to $\mathrm{CO}_{2}$ emissions. Demirba (2003) also argued that $\mathrm{CO}_{2}$ and $\mathrm{CO}$ are the main greenhouse gases (GHGs) associated with global warming. $\mathrm{CO}_{2}$ is responsible for about $50 \%$ of the greenhouse effect, the remainder being due to $\mathrm{CH}_{4}, \mathrm{CFCs}$, halogens, $\mathrm{N}_{2} \mathrm{O}$, $\mathrm{SO}_{2}$, ozone and peroxyacetylnitrate, which are all produced by industrial and domestic activities (Dincer 2001). MacKay \& Ko (2001) suggested that trends in monthly temperature anomalies are attributable to the combinations of GHGs.

China is the world's second largest producer of greenhouse gases, and with its rapid economical development, its emissions will increase substantially in the future. Rapid economic expansion will need much higher inputs of primary energy and will release more greenhouse gases. In their study of the 1951-1990 warming in China, Zhai \& Ren (1997) found that warming mainly occurred at night, which indicated that greenhouse effects intensify continuously. Of course, the greenhouse effect is not completely caused by human activities; the natural variation of the atmospheric moisture and land surface vegetation can also affect the greenhouse effect to some degree. China's GHG emissions have fallen since 1996 (Streets et al. 2001), but the growing population and economy will result in higher longterm releases. 


\subsubsection{Sulfate aerosol-induced cooling}

Aerosols of anthropogenic origin can have significant climatic impacts, especially at the regional scale (e.g. Wigley 1989, Charlson et al. 1990, 1992, Kiehl \& Briegleb 1993, Jones et al. 1994, Penner et al. 1994, Haywood et al. 1997, Myhre et al. 1998, Haywood \& Boucher 2000, Kiehl et al. 2000). Anthropogenic aerosol effects are believed to be especially important over East Asia because of the rapid economic development of the region and the consequent increase in pollution emissions. Smith et al. (2001) estimated that the centrally planned Asia (CPA) region, dominated by China, is the largest contributor to global sulfur dioxide emissions.

Sulfate aerosols can enhance cloudiness, causing more solar radiation to be reflected back into space, a negative forcing effect that suppresses the signal of global warming. Also, sulfate aerosols themselves are reflective even in clear skies. Giorgi et al. (2002) conducted a series of multi-year regional simulations aimed at assessing the direct radiative forcing and climatic impact of anthropogenic sulfate and fossil fuel soot. Using observed emissions of anthropogenic $\mathrm{SO}_{2}$, they found that the direct effects of anthropogenic sulfate and soot can induce a surface cooling of -0.1 to $-0.7^{\circ} \mathrm{C}$, highly variable at the subregional scale and statistically significant over some regions of China. They found that the aerosol radiative forcing is greatest over the Sichuan Basin of SW China and over some areas of east and NE China. The forcing induces a surface cooling, which is also greatest over the Sichuan Basin. Evidence of a possible anthropogenic aerosol signal in the climate record over China has been presented, for example, by Qian \& Giorgi (2000). They observed a statistically significant cooling trend over the Sichuan Basin, corresponding to increasing atmospheric aerosol optical density. The indirect effects appear to explain the observed temperature record over some regions of China, at least in the warm season (Giorgi et al. 2003).

\subsubsection{Surface process-induced warming}

Surface processes are expected to have a very different impact on climate from that of the greenhouse effect: their impact is local, not global. Laat \& Maurellis (2003) concluded that local surface temperature increases are linked to the degree of industrialization, and their findings showed that a significant part of the observed warming is related to processes other than greenhouse warming. Therefore, surface processes such as changes in land use and the urban heat effect have an important influence on observed surface temperature changes (Gallo et al. 1996, 1999, Kalnay \& Cai
2003). Verburg et al. (1999) found that the most important land use conversions in China are caused by urbanization, desertification and afforestation.

Ogunjemiyo et al. (2003) showed that the surface cover types accounted for about $90 \%$ of the variations in the measured airborne fluxes of $\mathrm{CO}_{2}$, sensible heat and latent heat. Li et al. (2002) concluded that change in vegetation cover can result in soil desiccation, thus further affecting the temperature regime. Managed grasslands are also major contributors to the biosphere-atmosphere exchange of GHGs, with fluxes closely linked to management practices, soil type and climatic conditions (Soussana et al. 2004). Fu (2003) showed that, by altering the complex exchanges of water and energy from surface to atmosphere, changes in land cover have brought about significant changes to the East Asian monsoon. The anthropogenic modification of the monsoon system will probably influence regional temperature change in China. Forests also affect the climate, and Hodge $(2000)^{1}$ found that replanted forests absorb much less $\mathrm{CO}_{2}$ than do natural forests, thus leaving more GHGs in the atmosphere. In North China, land cover change is driven by desertification.

Urbanization is one of the strongest forces that drive changes in land use. The processes of agricultural restructuring, rural industrialization, and rapid urbanization in China since the 1990s have given rise to a marked loss of farmland in favor of market farming and non-agricultural developments (Lin \& Ho 2003). Urban expansion has changed land use/cover substantially from 1987 to 2001 (Xiao et al. 2005). Zhang et al. (2003) found that the rapid urbanization process induced by economic development has converted vast areas of cropland into urban and industrial surfaces. Between 1978 and 1995, the total cultivated land shrank from 99.4 to 95.0 million ha (CSSB 1996).

Although human activities impact temperature trends locally and regionally, latitude and topography are the dominating factors that affecting the warming pattern in China. This is in agreement with the gridded data analyzed by Lu et al. (2004), who found that land forms and latitude effects seem to be dominating factors influencing the climate of China in the 20th century.

\section{CONCLUSIONS}

Warming in China is greater in winter than in summer. Warming is also greater at higher latitudes, and the difference in warming between summer and win-

\footnotetext{
${ }^{1}$ Harper's Magazine Weekly Review. Available at http://harpers.org/WeeklyReview2000-09-26.html
} 
ter increases with latitude as well. The latitudinal difference between summer and winter warming is partly due to differences in continentality, and longitudinal differences in warming are influenced by the landforms and ocean. The seasonal variation in vegetation cover is probably a main factor for seasonal climate differences, particularly in northern China. Regional differences in seasonal warming also result from GHG and aerosol emissions. Aerosols are probably responsible for some of the cooling in southern China in summer. In China as a whole, however, temperature variation is still dominated by the natural factors of latitude and topography.

Acknowledgements. This study was supported by the Hundred Talents Program (CAS2002-43) of the Chinese Academy of Sciences, funds of the 'Great Project for Western China Development' (90302006), the Project for Outstanding Young Scientists (40121101) of the Chinese Natural Science Foundation, and the Outstanding Talents Support Program of Nanjing Normal University (2004-51). Thanks also to Dr. Madhav Khandekar and the editorial staff.

\section{LITERATURE CITED}

An Z, Wu X, Lu Y (1990) Primary study on environmental evolvement in the recent $20 \mathrm{ka}$. In: Liu D (ed) Loess, the Quaternary geology and global change, Vol 2. Science Press, Bingjing, p 1-26. (in Chinese)

Birchfield GE, Wertman J (1983) Topography, albedotemperature feedback, and climate sensitivity. Science 219:284-285

Chapman W, Walsh J (1993) Recent variations of sea ice and air temperature in high latitudes. Bull Am Meteorol Soc 74:33-47

Charlson RJ, Langner J, Rodhe H (1990) Sulphate aerosols and climate. Nature 348:22

Charlson RJ, Schwartz SE, Hales JM, Coakley RD, Hansen JE, Hoffman DJ (1992) Climate forcing by anthropogenic aerosols. Science 255:423-430

Chen X, Yu G, Liu J (2002) Mid-Holocene climate simulation and discussion of the temperature changing mechanism in eastern Asia. Science in China (Series D) 32(4):335-345 (in Chinese)

CSSB (China State Statistical Bureau) (1996) Statistical yearbook. China State Statistical Press, Beijing

Demirba A (2003) Energy and environmental issues relating to greenhouse gas emissions in Turkey. Energy Convers Manage 44(1):203-213

Dincer I (2001) Environmental issue. I. Energy utilization. Energy Source 23:69-81

Ding Y, Dai X (1994) Temperature variation in China during the last 100 years. Acta Meteorol 20(12):19-26

Du N, Kong Z, Shan F (1989) A preliminary investigation of the vegetational and climatic changes since 11,000 years in Qinghai Lake - an analysis based on palynology in core Qh85-14C. Acta Bot Sin 31:803-814

Fu C (2003) Potential impacts of human-induced land cover change on East Asia monsoon. Global Planet Change 37(3-4):219-229

Gallo KP, Easterling DR, Peterson TC (1996) The influence of land use/land cover on climatological values of the diurnal temperature range, J Clim 9:2941- 2944

Gallo KP, Owen TW, Easterling DR, Jameson PF (1999), Temperature trends of the historical climatology network based on satellite-designated land use/land cover. J Clim 12:1344-1348.

Giorgi F, Bi X, Qian Y (2002) Direct radiative forcing and regional climatic effects of anthropogenic aerosols over East Asia: a regional coupled climate-chemistry/aerosol model study. J Geophys Res 107:4439-4456

Giorgi F, Bi X, Qian Y (2003) Indirect vs. direct effects of anthropogenic sulfate on the climate of East Asia as simulated with a regional coupled climate-chemistry/aerosol model. Clim Change 58:345-376

Haywood JM, Boucher O (2000) Estimates of the direct and indirect radiative forcing due to tropospheric aerosols: a review. Rev Geophys 38:513-543

Haywood JM, Roberts DL, Slingo A, Edwards JM, Shine KP (1997) General circulation model calculations of the direct radiative forcing by anthropogenic sulfate and fossil-fuel soot aerosol. J Clim 10:1562-1577

Jones A, Roberts DL, Slingo A (1994) A climate model study of indirect radiative forcing by anthropogenic sulphate aerosols. Nature 370:450-453

Kalnay E, Cai M (2003), Impact of urbanization and land use change on climate. Nature 423:528-531

Kendall MG (1955) Rank correlation methods. Griffin, London

Kiehl JT, Briegleb BP (1993) The relative role of sulfate aerosols and greenhouse gases in climate forcing. Science 260:311-314

Kiehl JT, Schneider TL, Rasch PJ, Barth MC, Wong J (2000) Radiative forcing due to sulfate aerosols from simulations with the National Center for Atmospheric Research Community Climate Model. J Geophys Res 105:1441-1457

Kong Z, Du N, Zhang Y (1991) Finding and scientific significance of floral longan fossil in Jvronghuabaoshan Mountain. Quat Res (Beijing) 4:326-335

Laat ATJD, Maurellis AN (2004) Industrial $\mathrm{CO}_{2}$ emission as a proxy for anthropogenic influence on lower tropospheric temperature trends. Geophys Res Lett 31(5): 5204-5208 (doi: 10.1029/2003GL019024, 2004)

Li SG, Harazono Y, Zhao HL, He ZY, Chang XL, Zhao XY, Zhang TH, Oikawa T (2002) Micrometeorological changes following establishment of artificially established Artemisia vegetation on desertified sandy land in the Horqin sandy land, China and their implication on regional environmental change. J Arid Environ 52:101-119

Liu G, Leopold EB (2003) Pliocene cooling before the ice ages in North China. Acta Palaeontol Sin 42(1):31-38

Lu A, He Y, Zhang Z, Pang H, Gu J (2004) Regional structure of global warming across China during the twentieth century. Clim Res 27:189-195

MacKay RM, Ko MKW (2001) An analysis of simulated and observed global mean near-surface air temperature anomalies from 1979 to 1999: trends and attribution of causes. Chemosphere Global Change Sci 3(4):393-411

Mann HB (1945) Nonparametric tests against trend. Econometrica 13:245-259

Mitchell JFB, Johns TC (1997) On modification of global warming by sulfate aerosols. J Clim 10:245-267

Myhre G, Stordal F, Restad K, Isaksen ISA (1998) Estimation of the direct radiative forcing due to sulfate and SSO aerosols. Tellus 50B: 463-477

Ogunjemiyo SO, Kaharabata SK., Schuepp PH, MacPherson IJ, Desjardins RL, Roberts DA (2003) Methods of estimating $\mathrm{CO}_{2}$, latent heat and sensible heat fluxes from estimates of land cover fractions in the flux footprint. Agric For Meteorol 117 (3-4):125-144 
Penner JE, Charlson RJ, Hales JM, Laulainen NS and 6 others (1994) Quantifying and minimizing uncertainty of climate forcing by anthropogenic aerosols. Bull Am Meteorol Soc 75:375-400

Qian Y, Giorgi F (2000) Regional climatic effects of anthropogenic aerosols? The case of southwestern China. Geophys Res Lett 27:3521-3524

Serreze MC, Walsh JE, Chapin III, FS Osterkamp T and 6 others (2000) Observational evidence of recent change in the northern high-latitude environment. Clim Change 46: $159-207$

Shi Y, Kong Z (1993) Climate and environment of the Holocene optimum in China. Ocean Press, Beijing (in Chinese)

Smith SJ, Pitcher H, Wigley TML (2001) Global and regional anthropogenic sulfur dioxide emissions. Global Planet Change 29(1-2):99-119

Soussana JF, Pilegaard K, Ambus P, Berbigier P, and 21 others (2004) Annual greenhouse gas balance of European grasslands-first results from the GreenGrass project. Int Conf Greenhouse Gas Emissions From Agriculture-Mitigation Options and Strategies. Weiske, Leipzig, p 25-30

Streets DG, Jiang K, Hu X, Sinton JE, Zhang X, Xu D, Jacobson MZ, Hansen JE (2001) Recent reductions in China's greenhouse gas emissions. Science 294:1835-1837

Tang L, Shen C, Han H (1991) A preliminary research on the climate change during 7500-5000 aBP in the middownstream area of the Yangtse River. Mar Geol Quat Geol 11:73-85

Thompson LG, Yao TD, Davis ME and 7 others (1997) Tropical climate instability: the last glacial cycle from a Qinghai-Tibetan ice core. Science 276:1821-1825

Editorial responsibility: Madhav Khandekar, Ontario, Canada
Vaughan DG, Marshall GJ, Connolley WM, Parkinson C and 5 others (2003) Recent rapid regional climate warming on the Antarctic Peninsula. Clim Change 60:243-274

Verburg PH, Veldkamp A, Fresco LO (1999) Simulation of changes in the spatial pattern of land use in China. Appl Geogr 19:211-233

Wigley TML (1989) Possible climate change due to $\mathrm{SO}_{2}$ derived cloud condensation nuclei. Nature 339:365-367

Wright HE Jr, Kutzbach JE, Webb T (Editors) (1993) Global climates since the last glacial maximum. University of Minnesota Press, Minneapolis

Xiao J, Shen Y, Ge J, Tateishi R, Tang C, Liang Y, Huang Z (2005) Evaluating urban expansion and land use change in Shijiazhuang, China, by using GIS and remote sensing. Landscape Urban Plan (in press)

Yao T, Shi Y, Qin D, Jiao K (1998) The ice-core record in Guliya. In: Shi Y, Li J, Li B (eds) Upheaval and environment of the Tibetan Plateau in the late Cenozoic. Science and Technology Press, Guangzhou, p 249-295 (in Chinese)

Zhai $\mathrm{P}$, Ren F (1997) On changes of China's maximum and minimum temperatures in the recent 40 years. Acta Meteorol Sin 55(4):418-429

Zhang GP, Liu JY, Zhang ZX (2003) Spatial-temporal changes of cropland in China over the past 10 years based on remote sensing. Acta Geogr Sin 158(3):323-332

Zhang L (1993) Research on the historical living environmental evolvement, Vol 1. Ocean Press, Beijing (in Chinese)

Zhang YL, Qin BQ, Chen WM (2004) Analysis of 40 year records of solar radiation data in Shanghai, Nanjing and Hangzhou in Eastern China. Theor Appl Climatol 78: $217-227$

Submitted: October 15, 2004; Accepted: March 24, 2005 Proofs received from author(s): April 26, 2005 